\title{
SIMULASI PENENTUAN TITIK PERTEMUAN SISTEM MANUFAKTUR BERTINGKAT PUSH DAN PULL
}

\author{
Chairul Saleh \\ Laboratorium Sistem Produksi, Jurusan Teknik Industri \\ Universitas Islam Indonesia, Yogyakarta \\ dr_chairul@yahoo.com
}

\begin{abstract}
Production control systems for multistage manufacturing processes can be classified into push type (MRP) and pull type (JIT) systems. MRP and JIT system has its own unique advantages and disadvantages, and the advantages of both systems can be exploited to achieve better performance. A relatively new research trend associated with the MRP and JIT is to explore the possibility of hybrid system and to develop model for the integrated system. So, the choice of a production philosophy by a manufacturing company is important. The key components of overall profitability are holding cost inventory, WIP, setup time and cost for missing due date on costumer order. The optimum lot-size associated with those of the key component. This paper presents an optimal lot-size production and integrated hybrid system with movable junction point between a Push sub-system and a Pull sub-system in production line using simulation approach. Using ARENA ${ }^{\circledR}$ simulation software this model could solve the problem. The result can achieve minimum production cost with production output level for push system of 79 to 82 unit, decreasing WIP from 85.81 hour to 84.165 hour per cycle and decreasing waiting time in works station 2 to 5.

Keywords : Push/Pull System, Lot-size, WIP, Manufacturing System
\end{abstract}

\section{PENDAHULUAN}

Beberapa sistem produksi yang banyak dikenal adalah sistem Material Requirement Planning (MRP), Just In Time (JIT) dan Optimum Process Technology $(O P T)$. Ketiga sistem ini masing-masing memiliki kelebihan dan kelemahan serta pengaplikasiannya yang berbeda-beda. Sebagian besar industri saat ini menggunakan sistem MRP dibandingkan JIT dan OPT. Beberapa penelitian telah dilakukan dan menyatakan bahwa sistem JIT relatif lebih baik dibandingkan sistem yang lain. Sehingga banyak industri-industri yang menggunakan sistem MRP berkeinginan berubah ke sistem JIT.

Untuk melakukan perubahan sistem diperlukan waktu yang lama disamping itu investasinya sangat mahal. Perubahan sistem industri dapat diartikan merubah keseluruhan industri menjadi sistem industri yang baru sehingga dapat berakibat pada investasi yang sangat tinggi. Perubahan dari sistem MRP menuju JIT adalah tidak mudah untuk dilaksanakan disamping investasinya sangat tinggi, hal ini disebabkan perubahan sistem industri berhubungan dengan beberapa faktor. Misal faktor manusia, layout, sumber daya, budaya organisasi serta budaya bekerja. Sangat dimungkinkan, jika perubahan MRP menuju JIT harus dilakukan secara sekaligus akan diadakan penambahan serta pengurangan peralatan yang akan berpengaruh pada kondisi tata letak fasilitas perusahaan. $\mathrm{CV}$ Dinamik merupakan perusahaan yang bergerak dalam bidang pembuatan meubel TEKNOIN, Vol. 11, No. 1, Maret 2006, 1-12 
antik dan furniture. Perusahaan ini diharapkan untuk menghasilkan produk yang berkualitas supaya dapat bersaing di pasar internasional. Untuk mencapai hasil suatu produk yang baik dan dengan biaya yang minimal diperlukan suatu sistem produksi yang tepat dan efisien. Perusahaan ini menjalankan proses produksinya dengan sistem MRP dan berkeinginan melakukan peningkatan kinerja dengan melakukan perubahan sitem produksi mengaruh pada sistem Pull. Disebabkan perubahan sistem ini mahal, maka dilakukan simulasi terhadap perubahan sistem tersebut. Sesuai dengan kaedah dasar peningkatan effisensi maka perubahan dilakukan secara bertahap, yaitu dicari pada bagian lini perakitan manakah yang dapat memberikan kebaikan dan memungkinkan dapat dilaksanakan.

\section{PERTEMUAN SISTEM TEKAN DAN TARIK}

Dalam penerapan untuk tujuan memaksimalkan keuntungan maka sistem produksi pada suatu industri sangat menentukan. Sistem produksi tekan (Push System) dan sistem produksi tarik (Pull System) memiliki kelebihan dan kekurangan. Namun demikian sistem tekan lebih banyak digunakan dibanding sistem tarik, hal ini disebabkan munculnya sistem tekan lebih awal dibanding sistem tarik. Untuk selanjutnya sistem tekan disebut dengan Material Requirement Planning (MRP) dan sistem tarik disebut dengan Just In Time (JIT). Pada perkembangan teknologi saat ini sistem JIT lebih disukai disebabkan filosofinya adalah meminimalkan biaya inventori, waktu persiapan, dan lain sebagainya. Disamping itu sistem JIT banyak menggunakan alat yang lebih canggih dan memaksimalkan kinerja sumber daya manusianya.

MRP dikembangkan di Amerika dan JIT di Jepang. Keduanya merupakan sistem produksi yang sudah lama dijalankan. JIT merupakan sistem produksi yang berhasil dijalankan di Jepang. Kelebihan kedua sistem ini dapat dikaji secara lebih mendalam untuk mendapatkan hasil yang lebih baik. Beberapa penyelidik mendapatkan sesuatu yang menarik apabila kedua sistem ini digabungkan (Benton dan Shin, 1998). Sampai saat ini usaha menggabungkan kedua sistem ini masih terus dilakukan. Pertemuan sistem tekan dan tarik dapat dilakukan dengan sistem produksi bertingkat jenis seri dan parallel. Hodgson dan Wang (1991) telah melakukan penelitian sistem tekan/tarik dengan menggunakan delapan strategi pertemuan pada sistem pembuatan bertingkat lima, jenis parallel dengan pendekatan kaedah Markov.

Untuk melakukan perubahan dari sistem MRP ke JIT tidaklah mudah karena diperlukan investasi yang besar, sehingga untuk merubahnya perlu dilakukan usaha secara bertahap. Namun demikian hal ini sukar dilakukan karena harus menentukan titik pertemuan sistem MRP dan JIT seperti yang telah dilakukan oleh beberapa peneliti. Cochran dan Kim (1998) telah meneliti pencarian titik optimal pertemuan JIT dan MRP beserta tingkat inventorinya dalam susunan seri. Dalam pertemuan kedua sistem ini, peranan jenis mesin, jumlah mesin yang digunakan, jenis dan jumlah produk yang dikeluarkan adalah amat penting untuk ditentukan dengan benar karena akan mempengaruh biaya pembuatan. Namun, kajian yang dilakukan oleh Cochran dan Kim tidak memperkirakan peranan mesin, jumlah mesin dan jenis outputnya. Kemudian Chairul Saleh, et.al, (1999) 
telah membuat suatu model matematis untuk menentukan titik pertemuan sistem produksi bertingkat tekan dan tarik sebagai berikut :

$$
\begin{aligned}
& \text { MinimumTC } \left.=\sum_{N v=1}^{v} \sum_{m=1}^{j}(\text { Setk }) N v \cdot m+\sum_{N u=T P+1 m=1}^{u} \sum_{(S e t k)}^{k}\right)_{n . k}+ \\
& h c_{N v . m}\left[\sum_{N v=1}^{v} \sum_{m=1}^{j}\left\{(W I P)+S S_{\text {tekan }}\right\}+\sum_{N u=T P+1 m=1}^{u} \sum_{K k}^{k}\left(\frac{D . . L T(1+S S)}{K k}-R p a\right)\right]+ \\
& D_{N v \cdot m}\left[\sum_{N v=1}^{v} \sum_{m=1}^{j}\left\{S t_{N v \cdot m}+p t_{\text {tekan }}+W_{\text {tekan }}\right\}\right]+ \\
& \operatorname{Dc}_{N v . m}\left[\sum_{N u=T P+1 m=1}^{u} \sum_{N=1}^{k}\left\{S t_{N v \cdot m}+p t_{\text {tarik }}+W_{\text {tarik }}\right\}\right]
\end{aligned}
$$

Pembatas
a. $\quad S t_{\mathrm{Nv} . \mathrm{m}-1}+\mathrm{pt}_{\text {tekan }} 0 \mathrm{St}_{\mathrm{Nv} \cdot \mathrm{m}}$
b. $\quad S t_{\mathrm{Nu} . \mathrm{m}-1}+\mathrm{pt}_{\text {tarik }} 0 \mathrm{St}_{\mathrm{Nu} . \mathrm{m}}$
c. $\mathrm{TP}+10 \mathrm{Nu} 0 \mathrm{U}$
d. $\quad 10 \mathrm{Nv} 0 \mathrm{TP}$
e. $\quad \sum\left(\frac{D L T(1+S S)}{k b}\right)-R p a \geq 0$

Dimana :

$S S=$ Bekalan keselamatan (Safety stock)

$\mathrm{TP}=$ Titik pertemuan sistem tekan-tarik

$Y=$ Jumlah Kanban

$H c=$ Biaya simpan

$D c=$ Biaya transportasi

$N v=$ Tingkat (stage) sistem pembuatan tekan $n=1,2,3 . . V .(\mathrm{V}=\mathrm{TP})$

$N u=$ Tingkat (stage) sistem pembuatan tarik $n=P T+1, P T+2, P T+3 . . U$

$V=$ Jumlah tingkat sistem pembuatan tekan

$U=$ Jumlah tingkat sistem pembuatan tarik

$M=$ Indeks mesin di setiap tingkat (stage) sistem tekan dimana $m=1,2,3 \ldots j$

$n=$ Indeks mesin di setiap tingkat (stage) sistem tarik dimana $n=1,2,3, \ldots k$

$j=$ Jumlah mesin sistem pembuatan tarik

$k=$ Jumlah mesin sistem pembuatan tekan

LT $=$ Lead time

$P t=$ Waktu proses

$S t=$ Waktu "start"

$K k=$ Kapasitas Kontainer

Setk = Biaya set up 
$R p a=$ Rata-rata permintaan aktual pada sistem tarik

WIP $=$ (Work In Proses) Inventori kerja yang sedang diusahakan

$($ Wtekan $)=$ Waktu menunggu proses pada sistem tekan

$($ Wtarik $)=$ Waktu menunggu proses pada sistem tarik

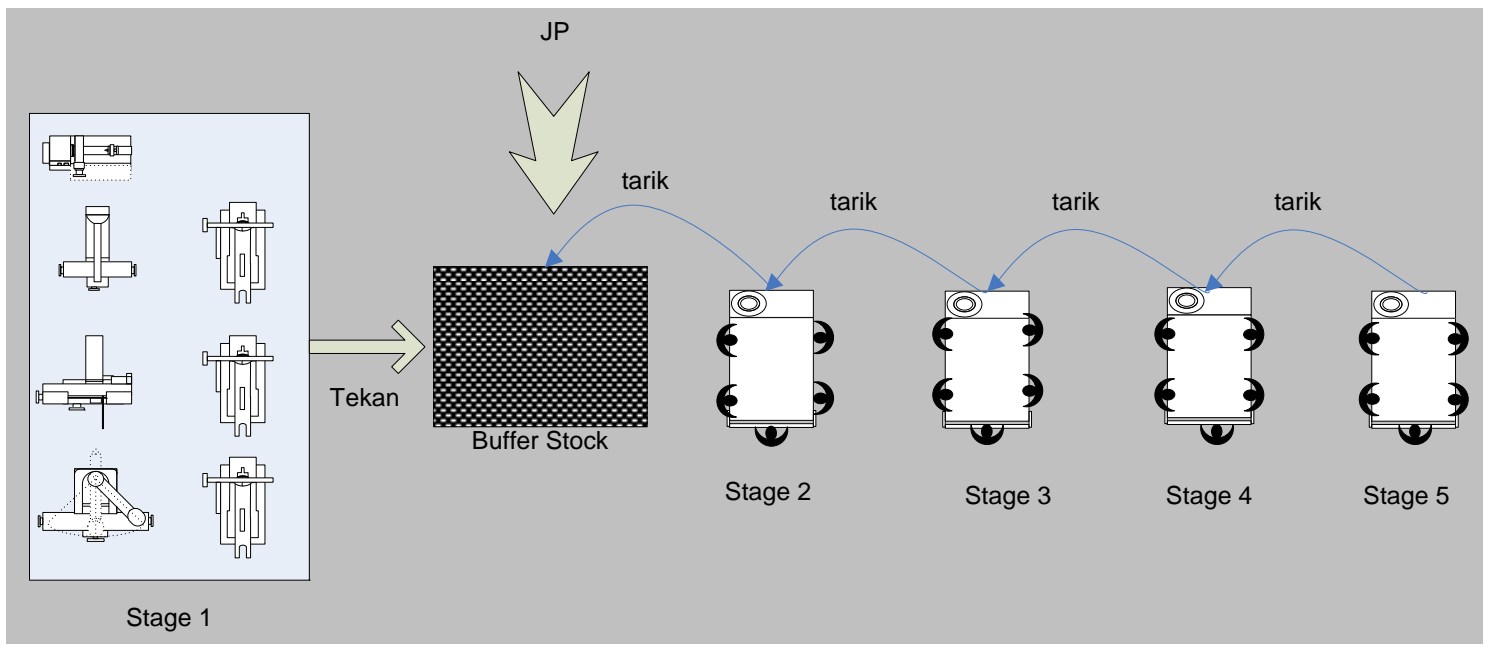

Gambar 1. Pertemuan Sistem Tekan Tarik

Penelitian terhadap model persamaan (1) yang menentukan titik pertemuan kedua sistem dengan biaya minimal telah dilakukan baik dengan optimasi metode simple heuristik, algoritma genetik. Penelitian yang dilakukan di CV Dinamik. Penelitian memberikan hasil yang signifikan (Chairul Saleh, 2005a, 2005b). Sejalan dengan keinginan CV Dinamik untuk meningkatkan kinerja produksinya maka berdasarkan penelitian sebelumnya ini perlu dilakukan simulasi terhadap sistem riil. Maksud penelitian simulasi ini adalah untuk dapat memperkirakan sistem riil yang akan dihadapi setelah dilakukan pertemuan kedua sitem Push dan Pull.

\section{KONSEP DASAR SIMULASI}

Untuk dapat memberikan pengertian yang jelas maka perlu dijelaskan halhal yang berhubungan dengan konsep dasar simulasi. Konsep dasar tersebut berhubungan dengan pengertian sistem, model dan simulasi sistem.

\subsection{Sistem}

Sistem merupakan kesatuan dari elemen-elemen yang terhubung melalui sebuah mekanisme tertentu dan terikat dalam hubungan interdependensi. Sistem memiliki sesuatu yang menjadi tujuan bersama. Dan lingkungan suatu sistem memiliki batas dengan sistem lain yang ada disekitarnya. Lingkungan sistem adalah segala sesuatu yang bukan merupakan bagian dari sistem, tetapi keberadaannya dapat mempengaruhi dan atau dipengaruhi sistem. Sistem juga 
memiliki hubungan yang bersifat umpan balik yang menyebabkan sistem senantiasa dinamis.

\subsection{Model}

Model merupakan suatu representasi atau formalisasi dalam bahasa tertentu dari suatu sistem riil yang disepakati (Banks, et.al., 1996). Sehingga model dapat dikatakan sebagai sebuah kesatuan yang menggambarkan karakteristik suatu sistem. Model dibuat dengan cara mensimplifikasi dari sistem.Untuk mempelajari sebuah sistem, dapat dilakukan dengan pengamatan pada model sistem tersebut. Walaupun model merupakan bentuk sederhana dari sebuah sistem, tapi dalam pembentukannya harus tetap memperhatikan kompetensi dari karakteristik sistem yang diamati.

Pada satu sistem yang sama dapat dibuat beberapa model yang berbeda, tergantung pada persepsi, kemampuan, dan sudut pandang analis sistem yang bersangkutan. Pada dasarnya model adalah suatu representasi yang memadai dari sebuah sistem.

\subsection{Simulasi Sistem}

Simulasi adalah imitasi dari sistem dinamik menggunakan model yang dijalankan dalam komputer supaya dapat dievaluasi dan ditingkatkan performansinya. Pemahaman utama adalah bahwa simulasi bukanlah alat optimasi yang memberi suatu keputusan hasil, namun hanya merupakan alat pendukung keputusan (decision support system). Simulasi menghilangkan biaya yang mahal, penggunaan waktu yang lama, dan menghindari kesalahan yang biasa dilakukan pada teknik coba-coba (Banks, et.al., 1996)

\subsection{Eksperimen Simulasi}

Tahapan ekperimen pada studi simulasi mempunyai tahapan metodologi yang secara umum dapat digunakan seperti yang ditunjukkan pada gambar 2 . Pada eksperimen ini digunakan alat bantu sofware Arena ${ }^{\circledR}$ (David, 2003). 

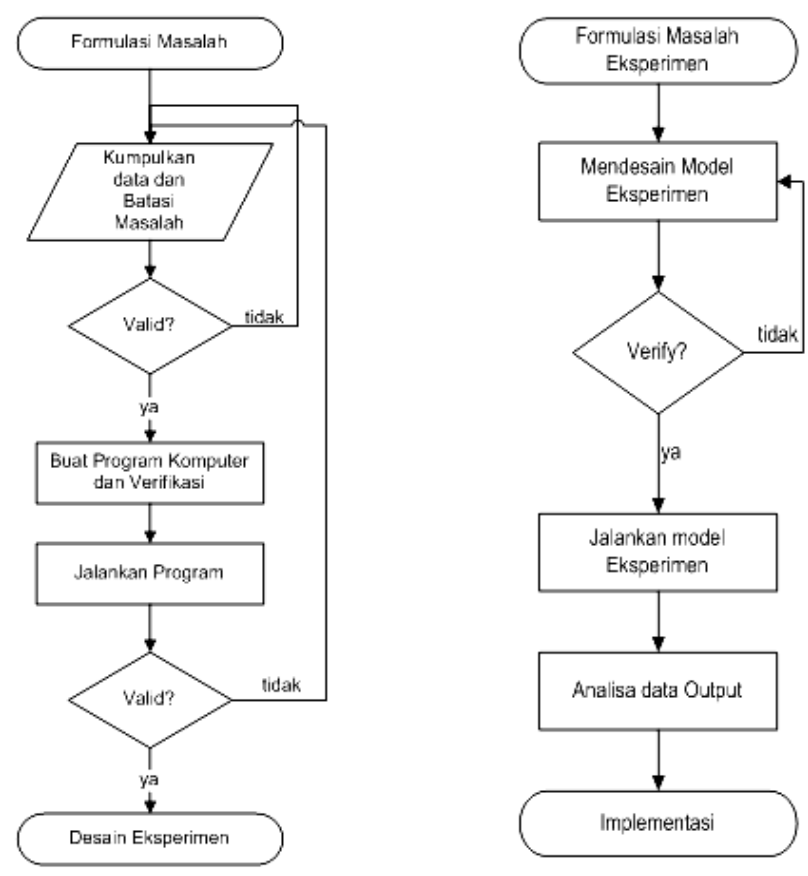

Gambar 2. Tahapan Ekperimen Studi Simulasi

\subsection{Proses Translasi Sistem Riil Menuju Model Simulasi}

Data yang digunakan dalam penelitian adalah data-data dari model sistem riil. Dalam menyusun program simulasi dari sistem riil yang diamati, maka diperlukan beberapa data input, diantaranya (1) waktu proses produksi setiap komponen pada masing-masing mesin. (2) delivery lead time (DLT) dari satu mesin ke mesin selanjutnya. (3) jumlah jam kerja. (4) urutan proses dan (5) Sumber seperti mesin dan operator.

Program simulasi direncanakan menggunakan waktu 480 menit sekali replikasi, yang menggambarkan 8 jam kerja. Replikasi yang dijalankan sebanyak 26 kali yaitu menunjukkan waktu kerja dalam sebulan.

Sistem yang dibangun adalah Sistem manufaktur bertingkat lima, dengan logika sistem proses produksi dilakukan dengan sistem tekan murni seperti pada Gambar 3. Langkah pembangunan model, yang dibangun merepresentasikan pengendalian sistem manufaktur bertingkat tekan murni, yaitu tingkatan proses dimulai dari produksi part hingga perakitan produk akhir. Dalam logika yang dibangun akan terjadi inventori part atau entitas yang akan diproduksi.

Penerjemahan ukuran performansi sistem yang diamati berdasarkan kepada jumlah produk jadi, WIP dan waktu siklus produksi. 

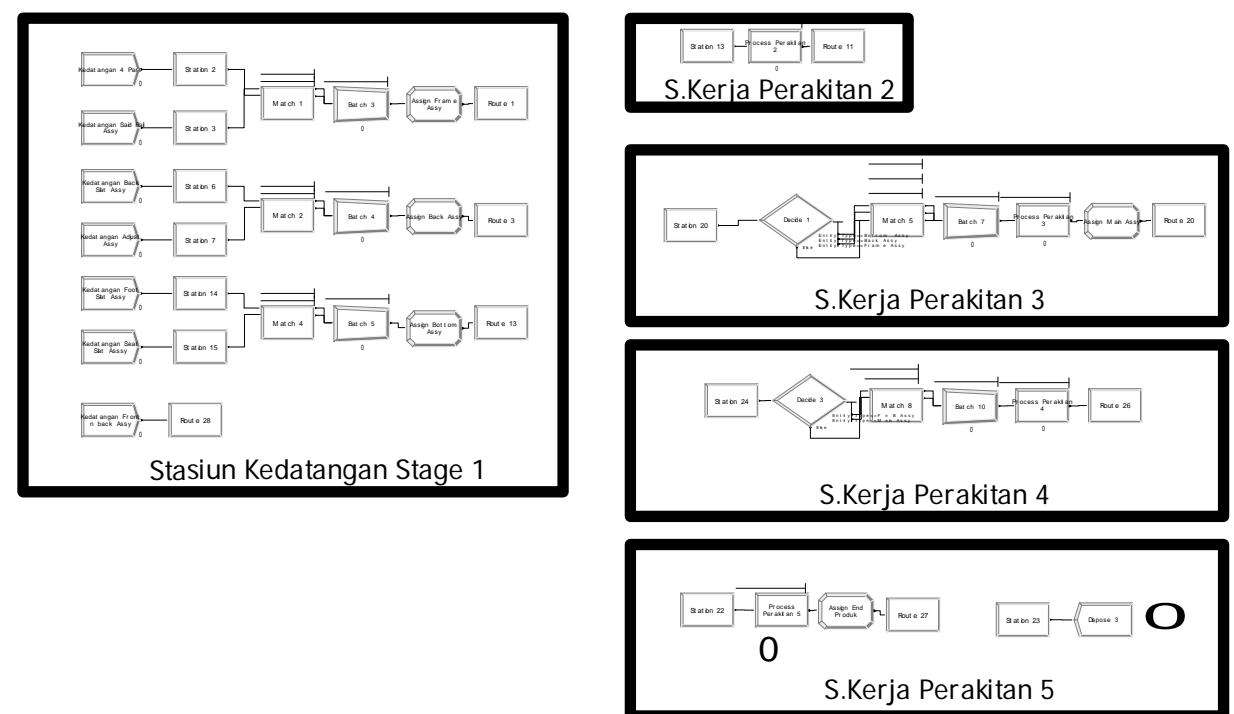

Gambar 3. Tampilan Sistem Tekan

\subsection{Validasi Model}

Data awal disimulasi sehingga diperoleh output, maka langkah selanjutnya adalah menguji perbedaan antara sistem riil dan sistem simulasi dan juga uji sensitivitas hasil dari model terhadap perubahan kecil pada parameter input. Jika hasilnya berubah secara ekstrim maka suatu estimasi yang baik harus diambil. Jika hasil diberikan simulasi sama dengan yang ada, maka data hasil dari simulasi tersebut dibandingkan dengan sistem riilnya. Jika hasilnya adalah sesuai maka program simulasi dinyatakan valid dan model dianggap representasi dari sistem riilnya. Berikut grafik output sistem simulasi dan data sistem riil yang dibandingkan melalui uji statistik.

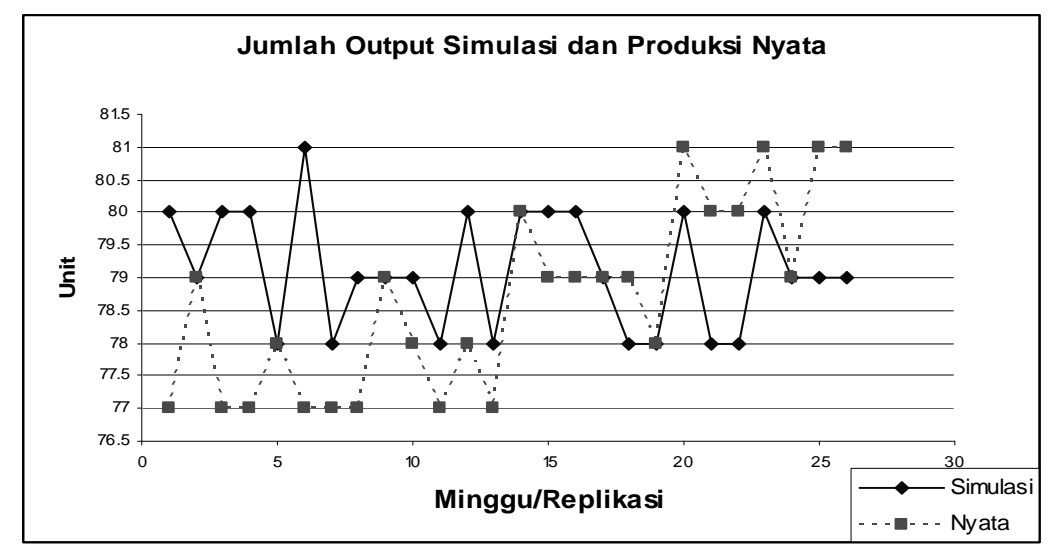

Gambar 4. Output sistem simulasi dan data sistem riil 
Tabel 1. Ringkasan Hasil Uji Validasi Model Sistem Tekan Murni Riil dan Simulasi

\begin{tabular}{|c|l|c|c|c|}
\hline No & \multicolumn{1}{|c|}{ Metode Validasi } & Batas Kritis & Nilai Statistik Uji & Keterangan \\
\hline 1 & Kecukupan Data/output & $\mathrm{N}=26$ & $\mathrm{~N}^{`}=0.13$ & Valid \\
\hline 2 & Keseragaman Output/data & $75.77-81.53$ & Mean $=78.65$ & Valid \\
\hline 3 & Kesamaan dua rata-rata & 3.198 & 1.383 & Valid \\
\hline 4 & Kesamaan Variansi & 1.313 & 0.398 & Valid \\
\hline 5 & Kecocokan Frekuensi & 5.99 & 1.38 & Valid \\
\hline
\end{tabular}

\section{MODEL PERTEMUAN SISTEM TEKAN DAN TARIK}

Model pengembangan yang dilakukan adalah mencari titik pertemuan sistem tekan dan tarik. Berdasarkan data manufaktur yang digunakan terdapat lima stage proses produksi dan dimungkinkan terjadi titik pertemuan ada stage 1 , $2,3,4$. Kemudian dibandingkan jumlah output produksi yang lebih banyak untuk dianalisa performance sistemnya.

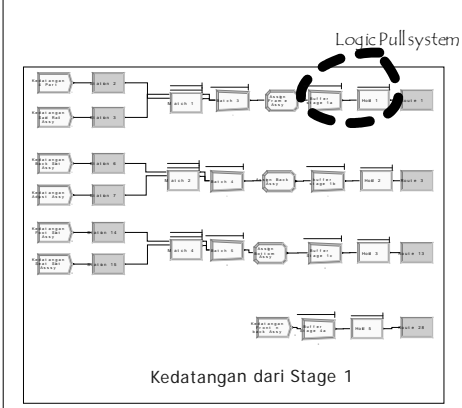

Hybrid Push/Pull System

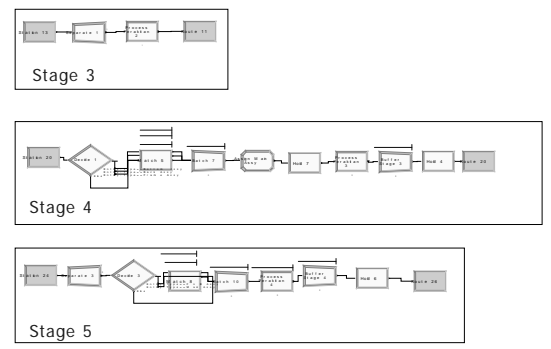

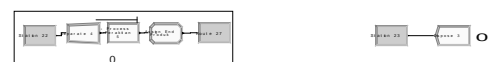

Gambar 5. Model Pertemuan (Hybrid) Sistem Push/Pull

Tabel 2. Kombinasi Titik Pertemuan

\begin{tabular}{|c|c|c|c|c|}
\hline \multirow{3}{*}{ Repli } & Setelah 1 & Setelah 2 & Setelah 3 & Setelah 4 \\
\cline { 2 - 5 } & $4-4-4-4$ & $4-4-4$ & 44 & 4 \\
\hline 1 & 80 & 78 & 76 & 80 \\
\hline 2 & 80 & 76 & 76 & 79 \\
\hline 3 & 80 & 76 & 80 & 80 \\
\hline 4 & 80 & 80 & 76 & 80 \\
\hline 5 & 80 & 76 & 76 & 78 \\
\hline 6 & 80 & 80 & 76 & 81 \\
\hline 7 & 80 & 78 & 80 & 78 \\
\hline 8 & 80 & 76 & 76 & 79 \\
\hline 9 & 80 & 78 & 80 & 79 \\
\hline 10 & 80 & 78 & 80 & 79 \\
\hline 11 & 80 & 76 & 76 & 78 \\
\hline 12 & 80 & 76 & 80 & 80 \\
\hline 13 & 80 & 77 & 76 & 78 \\
\hline
\end{tabular}

\begin{tabular}{|c|c|c|c|c|}
\hline \multirow{2}{*}{ Repli } & Setelah 1 & Setelah 2 & Setelah 3 & Setelah 4 \\
\cline { 2 - 5 } & $4-4-4$ & $4-4-4$ & $4-4$ & 4 \\
\hline 14 & 80 & 78 & 76 & 80 \\
\hline 15 & 80 & 80 & 77 & 80 \\
\hline 16 & 80 & 79 & 80 & 80 \\
\hline 17 & 80 & 76 & 76 & 79 \\
\hline 18 & 80 & 79 & 76 & 78 \\
\hline 19 & 80 & 78 & 80 & 78 \\
\hline 20 & 80 & 76 & 76 & 80 \\
\hline 21 & 80 & 76 & 80 & 78 \\
\hline 22 & 80 & 77 & 76 & 80 \\
\hline 23 & 80 & 78 & 80 & 78 \\
\hline 24 & 80 & 78 & 76 & 78 \\
\hline 25 & 80 & 76 & 80 & 79 \\
\hline 26 & 80 & 76 & 80 & 79 \\
\hline Ratarata & 80 & 77.38 & 77.73 & 79.08 \\
\hline
\end{tabular}


Ekperiemen dilakukan dengan ukuran lot tiap stage sama $=4$ unit. Diproleh hasil simulasi untuk titik pertemuan sistem tekan dan tarik seperti pada tabel 2: Ternyata diperoleh hasil titik pertemuan setelah stage 1. Ekperimen selanjutnya dilakukan dengan mengkombinasikan ukuran lot yang menghasilkan performansi yang lebih baik. Tabel $3-5$ serta Gambar 5 dibawah ini adalah hasil yang diperoleh dengan performansi terbaik.

Tabel 3. Output Produksi dengan ukuran Lot 4-3-2-2-2

\begin{tabular}{|c|c|}
\hline Rep & Jumlah \\
\hline 1 & 80 \\
\hline 2 & 82 \\
\hline 3 & 80 \\
\hline 4 & 82 \\
\hline 5 & 82 \\
\hline
\end{tabular}

\begin{tabular}{|c|c|}
\hline Rep & Jumlah \\
\hline 6 & 82 \\
\hline 7 & 82 \\
\hline 8 & 82 \\
\hline 9 & 80 \\
\hline 10 & 80 \\
\hline
\end{tabular}

\begin{tabular}{|c|c|}
\hline Rep & Jumlah \\
\hline 11 & 82 \\
\hline 12 & 82 \\
\hline 13 & 81 \\
\hline 14 & 82 \\
\hline 15 & 82 \\
\hline
\end{tabular}

\begin{tabular}{|c|c|}
\hline Rep & Jumlah \\
\hline 16 & 80 \\
\hline 17 & 80 \\
\hline 18 & 80 \\
\hline 19 & 80 \\
\hline 20 & 82 \\
\hline
\end{tabular}

\begin{tabular}{|c|c|}
\hline Rep & Jumlah \\
\hline 21 & 80 \\
\hline 22 & 82 \\
\hline 23 & 82 \\
\hline 24 & 80 \\
\hline 25 & 80 \\
\hline 26 & 82 \\
\hline
\end{tabular}

Tabel 4. Perbandingan Output Sistem Tekan Murni dan Gabungan

\begin{tabular}{|c|c|c|c|c|c|}
\hline \multicolumn{7}{|c|}{ Sistem Tekan } \\
\hline Repli & $\begin{array}{l}\text { Waktu } \\
\text { Siklus }\end{array}$ & WIP & $\begin{array}{c}\text { W. } \\
\text { Tunggu } \\
\text { Proses 2 }\end{array}$ & $\begin{array}{c}\text { W.Tunggu } \\
\text { Proses 3 }\end{array}$ & $\begin{array}{c}\text { W.Tunggu } \\
\text { Proses 4 }\end{array}$ \\
\hline 1 & 5.4336 & 84.642 & 1.357 & 1.2234 & 0.061 \\
\hline 2 & 5.4657 & 85.17 & 1.3924 & 1.2385 & 0.0455 \\
\hline 3 & 5.5736 & 86.764 & 1.4519 & 1.332 & 0.031 \\
\hline 4 & 5.4726 & 85.221 & 1.3793 & 1.273 & 0.043 \\
\hline 5 & 5.4949 & 85.693 & 1.4222 & 1.2876 & 0.0314 \\
\hline 6 & 5.4165 & 84.239 & 1.3495 & 1.233 & 0.0507 \\
\hline 7 & 5.5216 & 86.105 & 1.4308 & 1.2795 & 0.0297 \\
\hline 8 & 5.5669 & 86.672 & 1.4641 & 1.3034 & 0.0252 \\
\hline 9 & 5.5395 & 86.263 & 1.4568 & 1.2985 & 0.0253 \\
\hline 10 & 5.6139 & 87.335 & 1.5022 & 1.3486 & 0.0074 \\
\hline $\bar{X}$ & 5.4099 & 85.8104 & 1.42062 & 1.28175 & 0.03502 \\
\hline
\end{tabular}


Table 5. Gabungan Sistem Tekan dan tarik dengan ukuran Lot 4-3-2-2

Gabungan Sistem Tekan dan tarik dengan ukuran Lot 4-3-2-2

\begin{tabular}{|c|c|c|c|c|c|}
\hline Repli & $\begin{array}{c}\text { Waktu } \\
\text { Siklus }\end{array}$ & WIP & $\begin{array}{c}\text { W.Tunggu } \\
\text { Proses 2 }\end{array}$ & $\begin{array}{c}\text { W.Tunggu } \\
\text { Proses 3 }\end{array}$ & $\begin{array}{c}\text { W.Tunggu } \\
\text { Proses 4 }\end{array}$ \\
\hline 1 & 5.2321 & 84.32 & 0.2387 & 0.7238 & 0.2251 \\
\hline 2 & 5.214 & 83.775 & 0.24468 & 0.7646 & 0.2353 \\
\hline 3 & 5.2358 & 84.247 & 0.2365 & 0.7208 & 0.2297 \\
\hline 4 & 5.2372 & 84.013 & 0.2367 & 0.7224 & 0.2241 \\
\hline 5 & 5.2486 & 84.349 & 0.2397 & 0.7328 & 0.2315 \\
\hline 6 & 5.2308 & 84.079 & 0.2334 & 0.7268 & 0.2278 \\
\hline 7 & 5.2845 & 84.749 & 0.2121 & 0.7256 & 0.127 \\
\hline 8 & 5.2296 & 84.108 & 0.2398 & 0.6825 & 0.232 \\
\hline 9 & 5.2123 & 84.04 & 0.2376 & 0.7221 & 0.2323 \\
\hline 10 & 5.2197 & 83.969 & 0.2388 & 0.7147 & 0.2253 \\
\hline $\bar{X}$ & 5.23446 & 84.1649 & 0.235798 & 0.71175 & 0.21901 \\
\hline
\end{tabular}
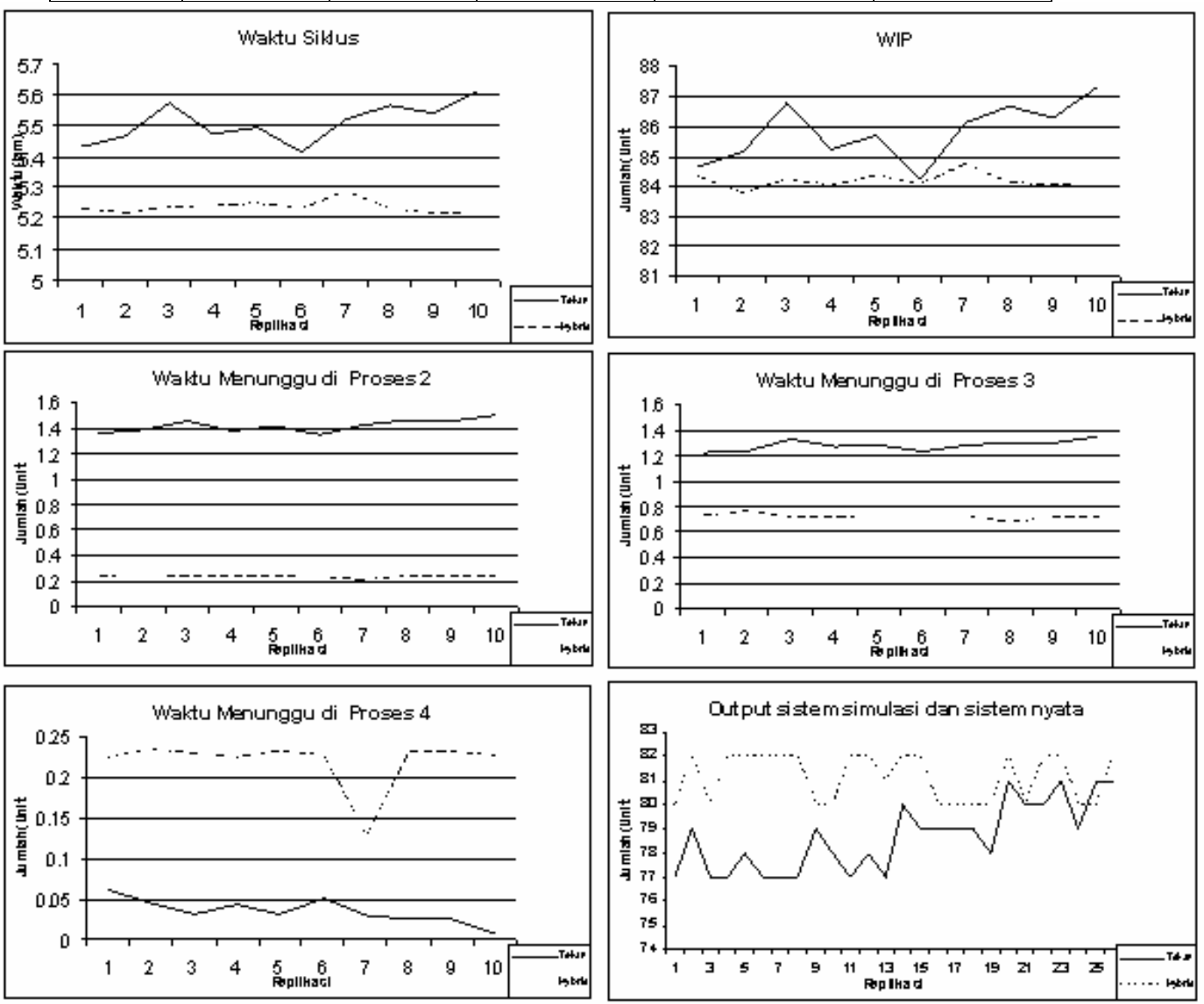

Gambar 5. Perbandingan Output Sistem Tekan dan pertemuan sistem tekan/tarik 


\section{SIMPULAN}

Dari hasil penelitian yang telah dilakukan oleh penulis, maka berikut ini adalah beberapa kesimpulan yang bisa diperoleh:

a. Model persamaan yang telah dikembangkan untuk sementara waktu secara teoritis dapat dibuktikan dan perlu dilakukan eksperimen kembali untuk menyakinkan bahwa hasil yang diperoleh dari simulasi ini dapat dijalankan pada industri tersebut.

b. Titik pertemuan optimum adalah pada stage 4 .

c. Dari pertemuan sistem tekan dan tarik didapatkan nilai TC perakitan minimum sebesar Rp. 4,930,948,- dengan ukuran lot produksi $=8$.

d. Dengan mengaplikasikan pertemuan sistem tekan/tarik, maka diperoleh peningkatan output produksi pada sistem tekan (push) murni output produksinya meningkat dari 78,63 unit menjadi 81.11 unit (79 menjadi 82).

e. $\quad$ Berdasarkan model simulasi, diketahui rata-rata WIP semula 85.8104 (86) unit menjadi 84,1649 (85) unit, dengan waktu siklus adalah 5,23 jam, waktu tunggu pada stasiun kerja $2=0.235$ jam, stasiun kerja $3=0.0,711$ jam, stasiun kerja $4=0.219$ jam, dan tidak ada waktu menunggu di stasiun kerja 5

\section{REKOMENDASI}

Penelitian ini perlu dilanjutkan dan perlu dibuktikan ketepatan model persamaan (1), dan juga perlu dikembangkan optimasi terhadap model menggunakan metode yang lain seperti kecerdasan buatan Simulated Annealing, Tabu Search dan Immune Algorithm

\section{PUSTAKA}

[1] Banks. J., Carsons. S.J., Nelson. B.L. (1996) Discrete-Event System Simulation, New Jersey Prentice Hall International edition

[2] Benton, Hojung, S. (1998). Manufacturing Planning and Control: The evolution of MRP and JIT integration, European Journal Production Research, Vol 110, 411-440

[3] Saleh, C., Hassan, A., Jamluddin, M.Y. (1999). Penentuan Optimum Saiz Kelompok Pada Titik Pertemuan Pertemuan Sistem Pembuatan Bertingkat Tekan/Tarik, Pascasidang Kajian dan Pengembangan, Penyelidikan ke Alaf Baru. Jabatan Kejuruteraan Mekanik dan Bahan, Universiti Kebangsaan Malaysia. 2-3 November

[4] Saleh, C. (2005). Optimasi Penentuan Titik Pertemuan Sistem Push Dan Pull Pada Lini Produksi Dengan Pendekatan Heuristik. Seminar Nasional Intelligent Control for Manufacturing System. Jurnal Teknoin, 23 Juli

[5] Saleh, C. (2005). Optimasi Biaya Produksi Pada Pertemuan Sistem Push Dan Pull Dengan Pendekatan Algoritma Genetik. Seminar Nasional Mesin dan Industri (SNMI) 2005. Riset Aplikatif Bidang Teknik Mesin dan Industri, Jakarta 2728 September 2005

[6] Cochran. J.K., Kim. S.S. (1998). A simultion approach to determine an optimum junction point in hibrid push and pull manufakturin sistem, Simulators XII Conference, Phoenix AZ. April 
[7] Cochran J.K., Kim S.S. (1998) Optimum junction point location and inventory levels in serial hybrid push and pull production Systems, International Journal Production Research, Vol. 36, no. 4, 1141-1155

[8] David, K. (2003) Simulation with Arena, McGraw Hill, New York

[9] Hirakawa. Y., Hoshino. K., Katayama. H. (1992) A hybrid push/pull production control system. International of Production Economics. 44.129 - 35

[10] Hodgson, T.J. \& Wang, D. (1991) Optimal hybrid Push/Pull control strategies for a parallel multistage system : Part I, International Journal Operation Research vol. 29 (6) pp. 1279-1287 